\title{
Mullerian Inhibiting Factor Deficiency
}

National Cancer Institute

\section{Source}

National Cancer Institute. Mullerian Inhibiting Factor Deficiency. NCI Thesaurus. Code C101215.

A deficiency of the Mullerian inhibiting substance, which is secreted by the Sertoli cells during embryogenesis. It can result in unilateral or bilateral cryptorchidism, testicular regression syndrome and sterility. 